\title{
PPARs as Metabolic Regulators in the Liver: Lessons from Liver-Specific PPAR-Null Mice
}

\author{
Yaping Wang ${ }^{1}$, Takero Nakajima ${ }^{1}$, Frank J. Gonzalez ${ }^{2}$ and Naoki Tanaka ${ }^{1,3, *(1)}$ \\ 1 Department of Metabolic Regulation, Shinshu University School of Medicine, Matsumoto, Nagano 390-8621, \\ Japan; 16mh281b@shinshu-u.ac.jp (Y.W.); nakat@shinshu-u.ac.jp (T.N.) \\ 2 Laboratory of Metabolism, National Cancer Institute, National Institutes of Health, Bethesda, MD 20892, \\ USA; gonzalef@mail.nih.gov \\ 3 Research Center for Social Systems, Shinshu University, Matsumoto, Nagano 390-8621, Japan \\ * Correspondence: naopi@shinshu-u.ac.jp; Tel.: +81-263-37-2851
}

Received: 21 February 2020; Accepted: 9 March 2020; Published: 17 March 2020

\begin{abstract}
Peroxisome proliferator-activated receptor (PPAR) $\alpha, \beta / \delta$, and $\gamma$ modulate lipid homeostasis. $\operatorname{PPAR} \alpha$ regulates lipid metabolism in the liver, the organ that largely controls whole-body nutrient/energy homeostasis, and its abnormalities may lead to hepatic steatosis, steatohepatitis, steatofibrosis, and liver cancer. PPAR $\beta / \delta$ promotes fatty acid $\beta$-oxidation largely in extrahepatic organs, and PPAR $\gamma$ stores triacylglycerol in adipocytes. Investigations using liver-specific PPAR-disrupted mice have revealed major but distinct contributions of the three PPARs in the liver. This review summarizes the findings of liver-specific PPAR-null mice and discusses the role of PPARs in the liver.
\end{abstract}

Keywords: PPAR; NAFLD; NASH; insulin resistance; liver fibrosis

\section{Introduction}

Administration of Wy-14643, nafenopin, and fibrate drugs to rodents results in hepatic peroxisome proliferation. These agents are thus designated as peroxisome proliferators (PPs) [1]. To explain a mechanism of rapid and drastic changes following PP administration, the involvement of transcription factors was assumed and the first peroxisome proliferator-activated receptor (PPAR, later defined as PPAR $\alpha$ (NR1C1)) was identified in 1990 [2]. Subsequently, two other PPARs, PPAR $\beta / \delta$ (NR1C2) and PPAR $\gamma($ NR1C3), were identified [3,4].

PPARs are activated by various ligands. For example, long-chain fatty acids (FAs) and eicosanoids are typical endogenous ligands for PPAR $\alpha$ and PPAR $\beta / \delta[5,6]$, whereas PPAR $\gamma$ is activated by arachidonic acid metabolites, such as 5-oxo-15(S)-hydroxyeicosatetraenoic acid and 5-oxo-eicosatetraenoic acid [7,8]. Many exogenous compounds (e.g., lipid-lowering fibrates) and several endocrine-disrupting chemicals, such as pesticides (diclofap-methyl, pyrethins, and imazalil), herbicides (2,4-dichlorophenoxyacetic acid), and phthalate esters (diethylhexyl phthalate) possess PPAR $\alpha$-activating properties in rodents $[9,10]$. Wy-14643 is a potent PPAR $\alpha$ activator that is widely used in experimental studies, but has some modest low-affinity PPAR $\beta / \delta$ - and PPAR $\gamma$-activating potential [4]. GW501516 is a highly-selective PPAR $\beta / \delta$ ligand, and anti-diabetic thiazolidinedione (TZD) derivatives, such as pioglitazone, GW1929, and GW2090, are specific PPAR $\gamma$ activators [11].

The expression of the three PPARs is quite different between organs, indicating their distinct physiological roles. Notably, PPAR $\alpha$ is expressed in hepatocytes, cardiomyocytes, proximal renal tubular cells, and brown adipocytes. PPAR $\beta / \delta$ is more ubiquitous but mainly found in skeletal muscle, skin, adipose tissue, heart, liver, and inflammatory cells. PPAR $\gamma$ has three splicing variant isoforms $(\gamma 1, \gamma 2$, and $\gamma 3)$ that display differences in tissue localization for each isoform despite the same DNA binding specificity: $\gamma 1$ (ubiquitous localization), $\gamma 2$ (localized in adipose tissue), and $\gamma 3$ (localized in 
macrophages, colon, and adipose tissue). The transcriptional activity of PPAR $\gamma 2$ is 5-10 times greater than that of PPAR $\gamma 1$ [12]. When PPAR $\alpha$ is activated by FA, FA $\beta$-oxidation and ensuing adenosine triphosphate (ATP) production and ketogenesis are enhanced, thus indicating that PPAR $\alpha$ is the main controlling factor for FA oxidation and energy generator under a nutrient-deprived state. On the contrary, when PPAR $\gamma$ is activated, several proteins, such as FA-binding protein 4 (FABP4, also known as aP2), are up-regulated and FAs are stored in adipocytes as triacylglycerol (TAG). Under conditions of nutrient overload and obesity, PPAR $\gamma$ is induced and activated in liver where it is involved in FA storage as lipid droplets $[13,14]$. Therefore, differences of PPARs in cell-specific expression, ligands, and target genes suggest a major but distinct contributions of the three PPARs to energy/nutrient metabolism in the liver.

Genetically-modified mice using Cre-LoxP system are useful tools for evaluating cell-specific roles of PPARs in vivo. This review summarized the recent findings of liver-specific PPAR-null mice, updated the knowledge regarding the role of PPARs in the liver, and discussed unsolved questions. All descriptions in this review refer to mouse PPARs unless otherwise specified.

\section{Role of PPAR $\alpha$ in the Liver}

Constitutive mitochondrial $\beta$-oxidation activity was significantly reduced in the livers of mice lacking PPAR $\alpha$ gene (Ppara-null mice) [15]. The fact that medium-chain acyl-coenzyme A (CoA) dehydrogenase and acyl-CoA oxidase 1 , the rate-limiting enzymes in mitochondrial and peroxisomal FA $\beta$-oxidation, respectively, are PPAR $\alpha$ target genes prompts consideration of a crucial role for PPAR $\alpha$ in FA catabolism and clearance (Figure 1). Polyunsaturated FAs (PUFAs) are endogenous activators of PPAR $\alpha$ [5,6], and when mice are fed a high-fat diet (HFD) without PUFAs for 5 weeks, they show high serum FA levels and severe fatty liver. Supplementation of the HFD with PUFAs, mainly linoleic acid and $\alpha$-linolenic acid, ameliorated fatty liver due to PPAR $\alpha$ activation and enhanced hepatic FA $\beta$-oxidation [16].

PPAR $\alpha$ is also involved in sphingolipid metabolism in the liver. Sphingolipids are a class of the complex lipids, having a ceramide structure, and are essential for diverse biological processes including development and growth. Sphingolipids are synthesized de novo, which is initiated from a condensation of L-serine and palmitoyl-CoA through serine palmitoyltransferase (SPT). SPT is a rate-limiting enzyme in overall sphingolipid biosynthesis, and PPAR $\alpha$ activation increases SPT gene expression in human skin cells and mouse livers $[17,18]$. PPAR $\alpha$ also controls palmitoyl-CoA synthesis by activating the gene encoding long-chain acyl-CoA synthetase [15]. Thus, PPAR $\alpha$ participates in regulation of the first step in sphingolipid biosynthesis by modulating SPT enzyme and palmitoyl-CoA levels.

PPAR $\alpha$ controls the synthesis of a certain sphingolipid class, sulfated glycolipid (sulfatide). Fenofibrate administration to mice up-regulated the expression of the gene encoding the sulfatidegenerating enzyme cerebroside sulfotransferase in a PPAR $\alpha$-dependent manner [19], resulting in increases in liver and serum sulfatide contents [20]. Because sulfatide has an anti-thrombotic effect [21], PPAR $\alpha$ activators might be useful for preventing cardiovascular diseases through induction of serum sulfatide production.

PPAR $\alpha$ also reflated the gene encoding fibroblast growth factor 21 (FGF21), a hepatokine secreted from the liver into blood, binding to a plasma membrane receptor complex on target tissues, mainly the FGF receptor 1 and $\beta$-Klotho heterodimer, and enhancing expression of glucose transporter 1 in extrahepatic tissues, leading to improved systemic insulin sensitivity and lipid turnover [22,23]. Hepatic and serum levels of FGF21 were significantly increased by PPAR $\alpha$ activation, whereas the constitutive levels were markedly lower in Ppara-null mice compared with wild-type mice [24]. These findings suggest that PPAR $\alpha$ 's control of hepatic metabolism is partially mediated by FGF21.

In response to prolonged fasting, circulating ketone bodies and FGF21 are increased. Recently, ketone bodies have attracted attention as not only an energy source of the brain, but also a substance correcting metabolic disease and preventing aging and cancer [25]. Expression of hydroxymethylglutaryl-CoA 
synthase 2, a rate-limiting enzyme of ketogenesis, is increased by PPAR $\alpha$ activation, and adaptive ketogenesis is impaired in Ppara-null mice [26].

Hepatic steatosis without ethanol consumption is designated as non-alcoholic fatty liver disease (NAFLD), which includes severe disease phenotype non-alcoholic steatohepatitis (NASH). NAFLD/NASH may progress to liver cirrhosis and hepatocellular carcinoma, and PPAR $\alpha$ may influence the severity of NAFLD/NASH [27-34]. In previous studies using liver tissues of NAFLD/NASH patients, PPAR $\alpha$ expression was lower with progression of fibrosis [34,35]. Hepatic PPAR $\alpha$ and circulating ketone bodies, indicators of FA utilization, were significantly low in hepatic steatosis/steatohepatitis in patients with citrin deficiency, a relatively common urea cycle disorder in the Asian population [36,37]. PPAR $\alpha$ also has anti-inflammatory properties through counteracting nuclear factor kappa B (NF- $\mathrm{kB}$ ) and enhancing FGF21 $[22,23,38]$. Previous studies suggest that PPAR $\alpha$ exerts anti-tumor effects in hepatoma cells by regulating NF- $\mathrm{kB}$ signaling [39]. Furthermore, oleoylethanolamide, an endocannabinoid-like endogenous molecule that binds PPAR $\alpha$ with high affinity, ameliorated thioacetamide-induced hepatic fibrosis in a PPAR $\alpha$-dependent manner [40]. These findings indicate that PPAR $\alpha$ ligands may exhibit not only anti-steatotic effects, but also anti-inflammatory and anti-fibrotic effects.

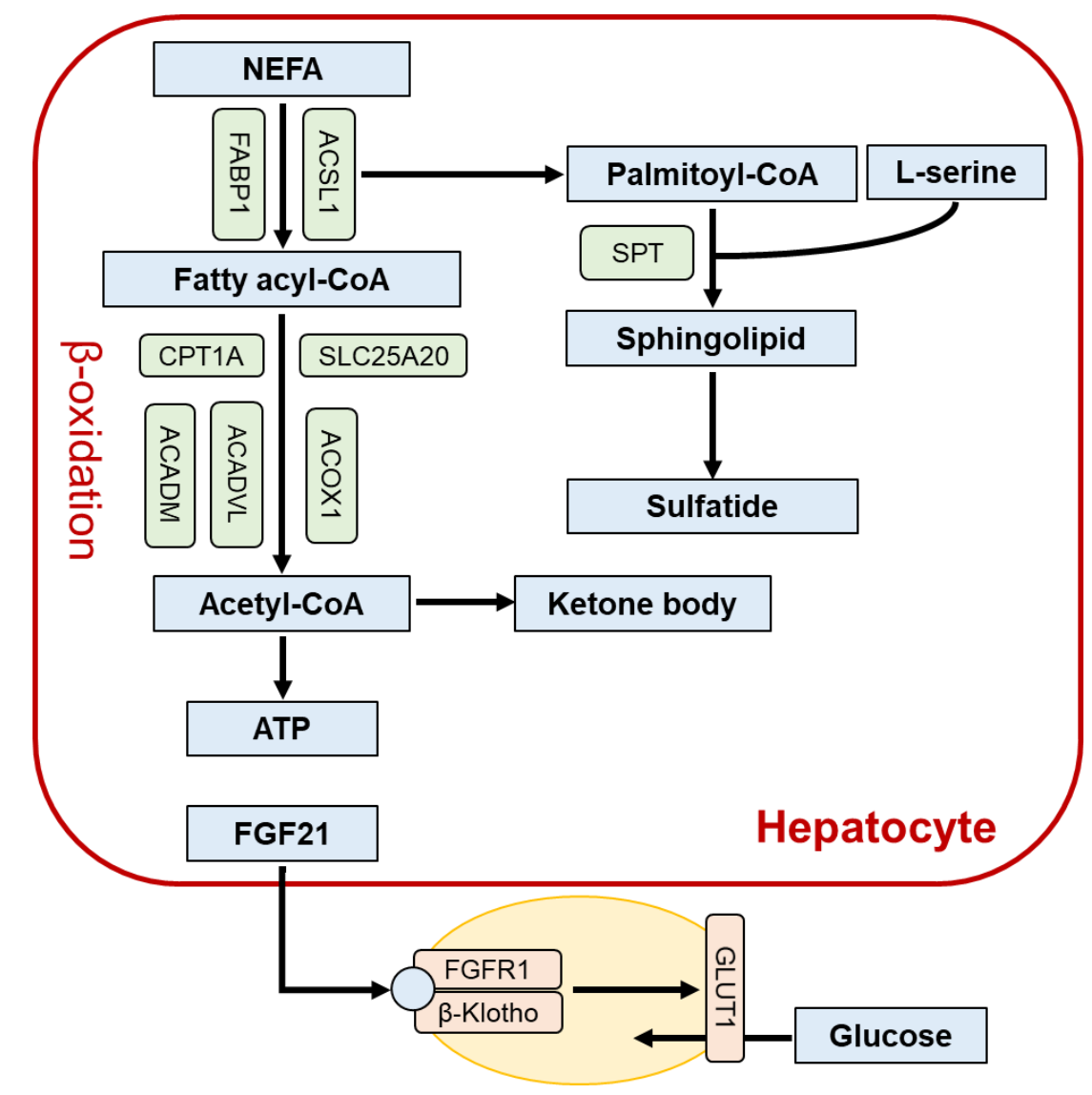

Extrahepatic tissue

Figure 1. The role of peroxisome proliferator-activated receptor $\alpha(\operatorname{PPAR} \alpha)$ in hepatic lipid metabolism. Enzymes/proteins up-regulated by PPAR $\alpha$ activation are indicated as green boxes. ACADM, medium-chain acyl-coenzyme A (CoA) dehydrogenase; ACADVL, very-long chain acyl-CoA dehydrogenase; ACOX1, acyl-CoA oxidase 1; ACSL1, acyl-CoA synthetase long chain family member 1; ATP, adenosine triphosphate; CPT1A, carnitine palmitoyltransferase I; FABP1, fatty acid-binding protein 1; FGF21, fibroblast growth factor 21; FGFR1, fibroblast growth factor receptor 1; GLUT1, glucose transporter 1; NEFA, non-esterified fatty acid; SLC25A20, solute carrier family 25 member 20; SPT, serine palmitoyltransferase. 


\section{Lessons from Liver-Specific Ppara-Null Mice}

Genetically modified mice using Cre-LoxP system provide useful information about cell-specific roles of PPARs in vivo. Although several PPAR $\alpha$ activators induce hepatomegaly and cell proliferation, it was unclear which hepatic cell type was mainly responsible for the function of PPAR $\alpha$ in lipid homeostasis and phenotypic changes following PP administration, such as hepatomegaly, hepatocyte proliferation, and liver cancer. Hepatocyte Ppara (Ppara ${ }^{\triangle \mathrm{HEP}}$ ) and macrophage Ppara (Ppara ${ }^{\triangle \mathrm{MAC}}$ )-specific knockout mice were treated with Wy-14,643 for 14 days. Hepatomegaly and hepatocyte proliferation were observed in wild-type and Ppara ${ }^{\triangle \mathrm{MAC}}$ mice, but not Ppara ${ }^{\triangle \mathrm{HEP}}$ and whole-body Ppara-null mice. On the contrary, down-regulation of pro-inflammatory cytokines interleukin (IL)-15 and IL-18 following Wy-14,643 treatment were dependent on the presence of macrophage PPAR $\alpha$. These results indicate the importance of cell specificity of PPAR $\alpha$ in its function [41].

Under the circumstance in which FAs are predominantly used as an energy source, such as fasting, Ppara-null mice cannot augment hepatic FA catabolism in response to increased FA influx from adipose tissue, resulting in severe hepatosteatosis [26]. Ppara ${ }^{\triangle \mathrm{HEP}}$ mice also exhibited more severe hepatic steatosis during fasting; ageing; and two NAFLD/NASH models, methionine- and choline-deficient diet and HFD feeding. Hepatic PPAR $\alpha$ activity was influenced by circulating FA through adipocyte lipolysis. During fasting, hepatocyte PPAR $\alpha$ disruption could not adjust liver metabolism to excess FA release from adipose tissues, resulting in aggravation of hepatic steatosis [42]. This adaptive response may be partially mediated by hepatokines, such as insulin-like growth factor-binding protein 1 and growth differentiation factor 15 [43].

The role of hepatocyte PPAR $\alpha$ for hepatic steatosis and liver-adipose axis was also intensively evaluated [44]. After a $24 \mathrm{~h}$ fasting cycle, hepatic FA accumulation was less in Ppara ${ }^{\Delta \mathrm{HEP}}$ mice compared to Ppara-null mice, although hepatic PPAR $\alpha$ target genes were similarly suppressed in both mice. In Ppara $^{\triangle \mathrm{HEP}}$ mice, the expression of genes encoding FA $\beta$-oxidation enzymes and lipase activity were increased in brown adipose tissue, heart, and muscle. Therefore, when hepatic PPAR $\alpha$ is disrupted, extrahepatic PPAR $\alpha$ activity compensates to increase and utilize excess lipid, thus protecting livers against fasting-induced steatosis [44].

\section{Role of PPAR $\beta / \delta$ in the Liver}

Activation of PPAR $\beta / \delta$ may prevent dyslipidemia, insulin resistance, obesity, and NAFLD [45]. Compared to other two PPARs, PPAR $\beta / \delta$ expression levels are far higher in muscle and PPAR $\beta / \delta$ is activated in muscle during the fed state and with exercise, increasing fuel consumption and $\beta$-oxidation [46]. PPAR $\beta / \delta$ activation increases liver glucose catabolism by inducing glucose 6 -phosphate dehydrogenase activity, inhibiting liver glucose output, suppressing FA release from white adipose tissue, and promoting $\beta$-oxidation in muscle. Mice lacking PPAR $\beta / \delta$ gene (Ppard-null mice) had lower metabolic activity and glucose intolerance uniformly [47].

Metabolic syndrome-related dyslipidemia is mainly caused by liver overproduction of TAG-containing lipoproteins. PPAR $\beta / \delta$ agonists showed a strong TAG-decreasing effect, which amplifies the PPAR $\gamma$ coactivator $1 \alpha$ pathway by the restoration of adenosine monophosphate-activated protein kinase (AMPK) activity in the liver [48]. In obese monkey, PPAR $\beta / \delta$ activation by the potent PPAR $\beta / \delta$ agonist GW501516 normalized serum insulin and TAG concentrations, decreased low-density lipoprotein cholesterol, and increased high-density lipoprotein cholesterol [49], which was also the case in diet-induced and genetically obese mice [50]. Although PPAR $\beta / \delta$ mediates the transcriptional response to native very low density lipoprotein (VLDL) in macrophage [51], Ppard-null mice were found to exhibit up-regulation of hepatic VLDL receptor due to activation of heme-regulated eukaryotic translation initiation factor $2 \alpha$ kinase and nuclear factor erythroid 2-related factor 2 [52].

The contribution of PPAR $\beta / \delta$ to hepatic lipid metabolism is summarized in Figure 2, but is somewhat controversial [53]. Intravenous injection of adenovirus with PPAR $\beta / \delta$ complementary DNA (cDNA) into $d b / d b$ mice resulted in activation of sterol regulatory element-binding protein (SREBP)-1, up-regulation of lipase, and improved liver steatosis [54]. In primary mouse hepatocytes and livers 
from HFD-fed mice, the PPAR $\beta / \delta$ agonist GW1516 up-regulated PPAR $\beta / \delta$-specific target genes Adfp and Cpt1 $a$ and enhanced FA oxidation. GW1516 also inhibited hepatic lipogenesis through activating AMPK and suppressing SREBP-1c [55]. Nevertheless, the other potent PPAR $\beta / \delta$ agonist GW501516 increased the expression of lipogenic enzyme acetyl-CoA carboxylase (ACC) 2 and resultantly augmented liver TAG content in $d b / d b$ mice, as done in reference [47]. It remains unclear whether these differences between GW1516 and GW501516 are derived from ligand affinities, specificities toward PPAR $\beta / \delta$, metabolism/distribution of the compounds, or other factors.

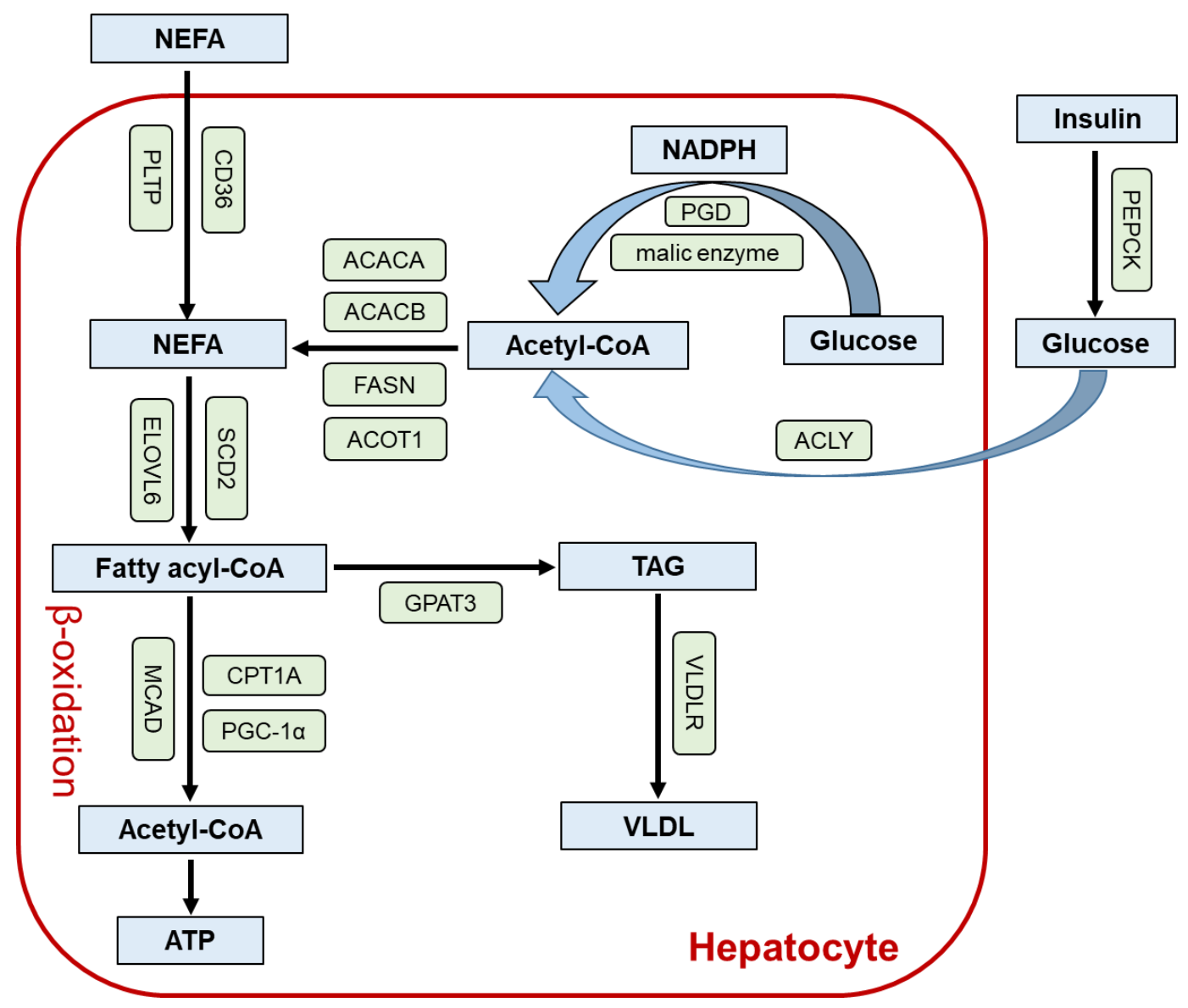

Figure 2. The role of PPAR $\beta / \delta$ in hepatic lipid metabolism. Enzymes/proteins up-regulated by PPAR $\beta / \delta$ activation are indicated as green boxes. ACACA, acetyl-CoA carboxylase 1 ; ACACB, acetyl-CoA carboxylase 2; ACLY, ATP citrate lyase; ACOT1, acyl-CoA thioesterase 1; CD36, cluster of differentiation 36; CPT1A, carnitine palmitoyltransferase I; ELOVL6, elongation of very long chain fatty acid-like family member 6; FASN, fatty acid synthase; GPAT3, glycerol-3-phosphate acyltransferase 3; NADPH, nicotinamide adenine dinucleotide phosphate; NEFA, non-esterified fatty acid; PEPCK, phosphoenolpyruvate carboxykinase; PGC- $1 \alpha$, peroxisome proliferator-activated receptor gamma coactivator 1-alpha; PGD, phosphogluconate dehydrogenase; PLTP, phospholipid transfer protein; SCD2, stearoyl-CoA desaturase 2; TAG, triacylglycerol; VLDL, very low density lipoprotein; VLDLR, VLDL receptor.

Similar to PPAR $\alpha, \operatorname{PPAR} \beta / \delta$ possesses anti-inflammatory effects in the liver by inhibiting NF- $\mathrm{KB}$ activity by directly binding to its subunit p65 [56-58]. In hepatitis B virus transgenic mice, PPAR $\beta / \delta$ activation in Kupffer cells ameliorated inflammation and prevented steatosis-induced hepatic tumorigenesis [59]. PPAR $\beta / \delta$ agonist L165041 and GW501516 increased hepatic expression of fibrosis markers in carbon tetrachloride $\left(\mathrm{CCl}_{4}\right)$-injected mice $[60,61]$, but not the agonist KD3010. Therefore, 
$\operatorname{PPAR} \beta / \delta$-specific agonists are attractive because PPAR $\beta / \delta$ activation can attenuate dyslipidemia, insulin resistance, hepatic steatosis, and inflammation [47,48,62-64].

Although preclinical data on PPAR $\beta / \delta$ agonists in metabolic diseases are quite encouraging, some conflicting but serious observations were found, bringing its utility as a drug target into question. GW501516-treated mice developed adenocarcinoma [65] and the PPAR $\beta / \delta$ agonist L-165041 increased hepatotoxicity due to hepatic stellate cell (HSC) activation [60]. However, the role of PPAR $\beta / \delta$ in carcinogenesis is controversial because conflicting studies indicate that PPAR $\beta / \delta$ inhibits and promotes tumorigenesis. It was proposed that heterogeneity in PPAR $\beta / \delta$ expression in cell types during tumorigenesis and the existence of natural PPAR $\beta / \delta$ agonists/antagonists and inverse agonists render the analysis of PPAR $\beta / \delta$ in cancer complex and controversial [66]. On the other hand, PPAR $\beta / \delta$ antagonism and inverse agonism have begun to attract attention, such as covalent antagonists GSK3787 and CC618 that were reported in studies on psoriasis and breast cancer, but the role in the liver is still unknown $[67,68]$.

A dual PPAR $\alpha / \beta$ activator elafibranor (GFT505) was developed, which showed beneficial effects for human NASH. In this GOLDEN-505 study, patients with NASH resolution after receiving elafibranor $120 \mathrm{mg}$ had reduced liver fibrosis stages compared with those without NASH resolution, and liver enzymes, lipids, glucose profiles, and markers of systemic inflammation were significantly reduced in the elafibranor $120 \mathrm{mg}$ group compared with the placebo group. Elafibranor was well tolerated without causing cardiac events or weight gain, but did produce a mild reversible increase in serum creatinine [69]. PPAR $\alpha / \beta$ dual regulators will be a major topic of basic scientific and clinical research in the coming years, thereby considering PPAR $\alpha / \beta$ activators for treatment of NASH in humans.

\section{Lessons from Liver-Specific Ppard-Null Mice}

Liu et al. examined the role of hepatic PPAR $\beta / \delta$ using an adenovirus-mediated PPAR $\beta / \delta$ overexpression and hepatocyte-specific Ppard-null (Ppard ${ }^{\triangle \mathrm{HEP}}$ ) mice [70]. Hepatic PPAR $\beta / \delta$ overexpression increased the expression of ACC1 but increased FA uptake and $\beta$-oxidation in isolated soleus muscle, leading to decreased circulating TAG and non-esterified FA levels. On the contrary, liver-specific ACC1 knockdown reduced hepatic TAG content but decreased FA uptake in muscles, suggesting linkage between hepatic PPAR $\beta / \delta$, hepatic lipogenesis, and muscle FA utilization. In Ppard ${ }^{\triangle \mathrm{HEP}}$ mice, hepatic induction of ACC1, ACC2, fatty acid synthase, and stearoyl-CoA desaturase 1 and increased muscle FA uptake during the dark cycle was abolished, suggesting that PPAR $\delta$ regulates circadian changes in hepatic lipogenic activity and muscle FA uptake. Indeed, increased expression of cluster of differentiation (CD) 36 and FABP3 in the muscle by PPAR $\beta / \delta$ ligand GW501516 was completely diminished in Ppard $^{\triangle \mathrm{HEP}}$ mice.

To further investigate the interconnection between hepatic PPAR $\beta / \delta$, hepatic lipogenesis, and muscle FA uptake, lipidomic analyses were performed. Liu et al. identified that phosphatidylcholine (PC) (18:0/18:1) (1-stearoyl-2-oleoyl-sn-glycero-3-phosphocholine) levels were increased by hepatic PPAR $\beta / \delta$ overexpression but decreased in Ppard ${ }^{\triangle H E P}$ mice [70]. Increased PC (18:0/18:1) levels by GW501516 treatment were diminished in Ppard ${ }^{\triangle \mathrm{HEP}}$ mice, and PC (18:0/18:1) treatment to myotubes increased FA uptake and CD36 and FABP3 expression. Furthermore, the effect of PC (18:0/18:1) on promoting FA utilization in muscle was abolished in Ppara-null mice and Ppara-depleted myotubes. Collectively, Ppard $^{\triangle \text { HEP }}$ mice identified a novel role of hepatic PPAR $\beta / \delta$ that enhances hepatic synthesis, muscle FA utilization, and improved dyslipidemia through a metabolic network between hepatic PPAR $\delta-P C$ (18:0/18:1)-muscle PPAR $\alpha$.

\section{Role of PPAR $\gamma$ in the Liver}

PPAR $\gamma$ is highly expressed in adipose tissue and macrophages, and plays important roles in adipogenesis, lipid metabolism, insulin sensitivity, and immune regulation [71]. PPAR $\gamma$ is expressed at much lower levels in the liver and muscle, but shows relatively high expression in the placenta [72]. 
In the past two decades, PPAR $\gamma$ has been a focus of attention as a transcription factor associated with metabolic syndrome.

The contribution of PPAR $\gamma$ to hepatic lipid metabolism is summarized in Figure 3. When PPAR $\gamma$ is ectopically overexpressed in hepatocytes, lipid droplets emerge. Adenovirus-mediated overexpression of PPAR $\gamma 2$ in hepatocytes increased hepatosteatosis and hepatocyte-specific disruption of PPAR $\gamma$ gene (Pparg) decreased liver steatosis in $o b / o b$ mice $[13,73]$. The notion that hepatic PPAR $\gamma$ expression promotes steatosis is supported by the facts that PPAR $\gamma$ up-regulates several proteins associated with lipid uptake, TAG storage, and formation of lipid droplets, such as FABP4, fat-specific protein 27 (FSP27)/Cidec, CD36, monacylglycerol O-acyltransferase 1, and perilipin 2 [74]. When the expression of adipogenic transcriptional factor genes Pparg and Srebp1c were observed during HFD feeding, Pparg2 mRNA levels rose before Srebp1c mRNA at 4 weeks [75], which were closely associated with adipogenesis-related protein, CD36, and fatty acid synthase [76,77]. A significant increase in hepatic PPAR $\gamma$ is one of the common phenotypes of steatotic animals associated with obesity [13] and without obesity, which lack TAG-storing capacity in adipocytes [78,79]. Similar overexpression of hepatic PPAR $\gamma$ was observed in NAFLD/NASH patients after pancreaticoduodenectomy, who were generally non-obese [80,81].

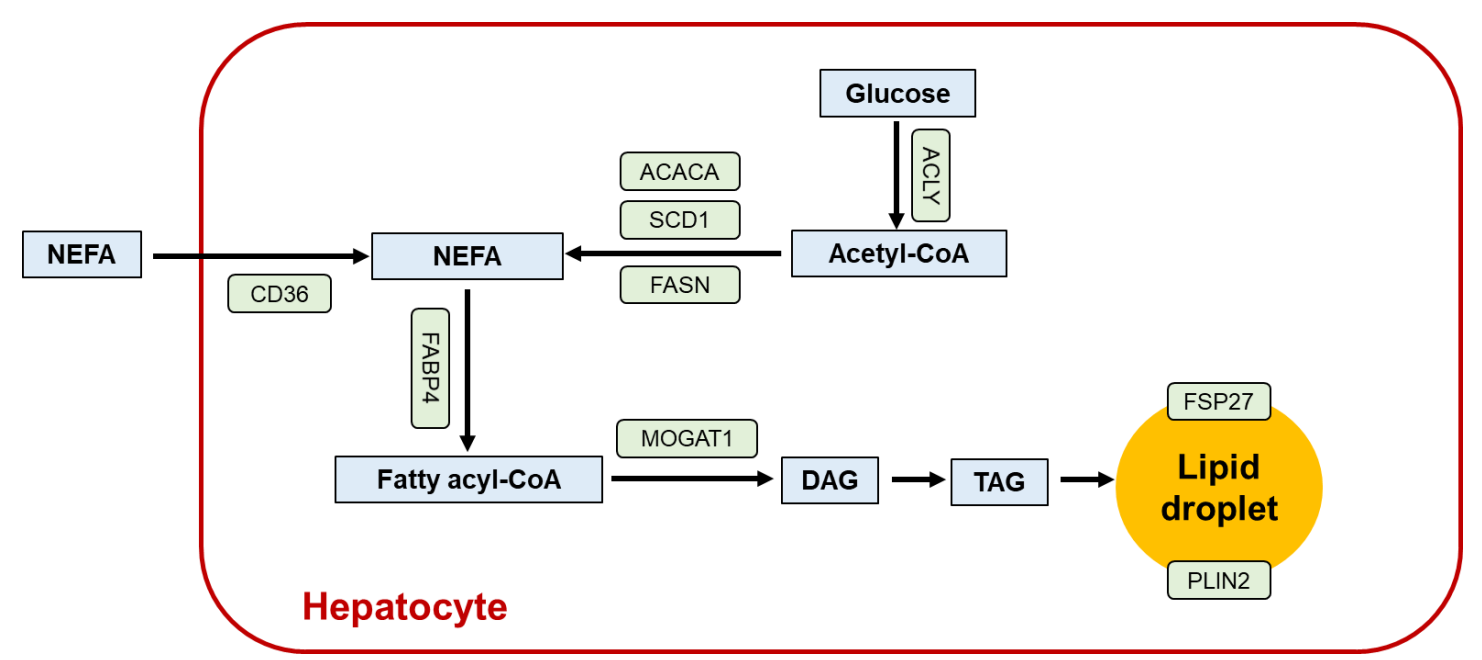

Figure 3. The role of PPAR $\gamma$ in hepatic lipid metabolism. Enzymes/proteins up-regulated by PPAR $\gamma$ activation are indicated as green boxes. CD36, cluster of differentiation 36; DAG, diacylglycerol; FABP4, fatty acid binding protein 4; FSP27, fat-specific protein 27 (cell death-inducing DNA fragmentation factor A-like effector c); MOGAT1, monoacylglycerol O-acyltransferase 1; NEFA, non-esterified fatty acid; PLIN2, perilipin 2; TAG, triacylglycerol.

Although activation of PPAR $\gamma$ is steatogenic, treating genetically obese or diet-induced NAFLD/NASH mice with PPAR $\gamma$ ligands decreases hepatic TAG. This distinct effect mainly stems from enhanced synthesis of adiponectin in adipose tissue [82]. Circulating adiponectin could increase glucose uptake and FA oxidation in hepatocytes by activating AMPK, thereby improving systemic insulin sensitivity and reducing liver steatosis [83]. PPAR $\gamma$ has significant anti-inflammatory properties, which can regulate the immune inflammatory response [84]. PPAR $\gamma$ activation reduced inflammatory response by negatively interfering with NF- $\mathrm{KB}$ and signal transducers and transcriptional activators [85], suppressed production of tumor-necrosis factor $\alpha$ and IL-1 $\beta$ in monocytes and macrophages, and polarized into anti-inflammatory M2 macrophage [86]. Compared with hepatocytes and Kupffer cells, PPAR $\gamma 2$ is highly expressed in quiescent HSC, and PPAR $\gamma$ is down-regulated during HSC activation [87]. PPAR $\gamma$ agonists could reduce hepatic fibrosis by restraining HSC proliferation and driving activated HSC to apoptosis [88]. 


\section{Lessons from Liver-Specific Pparg-Null Mice}

In Pparg ${ }^{\triangle \mathrm{HEP}}$ mice, expression of genes associated with adipogenesis and FA uptake were down-regulated. Paradoxically, exacerbation of systemic insulin resistance, adiposity, and hyperlipidemia against reduced hepatic steatosis in diabetic Pparg ${ }^{\triangle \mathrm{HEP}}$ mice corroborated that liver PPAR $\gamma$ protects other tissues from TAG accumulation and insulin resistance [89]. Lipoatrophic A-ZIP/F-1 mice disrupting hepatocyte Pparg reduced hepatic steatosis but aggravated hyperlipidemia and muscle insulin resistance [89]. Insulin resistance found in these mice was resistant to rosiglitazone, suggesting that in the absence of adipose tissue, the liver is a primary target for TZD action. In contrast, the finding that rosiglitazone remained effective in wild-type Parg $^{\triangle \mathrm{HEP}}$ mice demonstrated that adipose is the major site of TZD action in mice with normal adipose tissue.

Rosiglitazone could inhibit NF- $\mathrm{KB}$ activation and hepatic fibrosis after bile duct ligation in wild-type mice, but these changes disappeared in Pparg ${ }^{\triangle \mathrm{HEP}}$ mice, suggesting a key role for PPAR $\gamma$ in the context of biliary fibrosis [90].

Macrophages accumulate in adipose tissue during obesity, promote inflammation, and impair insulin sensitivity. However, HFD-induced hepatic steatosis was milder in Pparg $\triangle \mathrm{HEP}$ mice compared with Pparg ${ }^{\triangle \mathrm{MAC}}$ mice [91]. Compared with Pparg ${ }^{\triangle \mathrm{HEP}}$ mice and control mice, Pparg ${ }^{\triangle \mathrm{MAC}}$ mice and mice where Pparg is specifically disrupted in HSC showed aggravation of hepatic necroinflammation and fibrosis after repeated injections of $\mathrm{CCl}_{4}$. These results revealed that PPAR $\gamma$ in non-parenchymal cells mainly contributes to inflammatory response and ensuing fibrogenesis in the liver [92].

\section{The Other Factors Modulating Hepatic PPAR Function}

Environmental factors, such as nutrients, could modify the liver PPAR activity. For example, extra-virgin olive oil with high phenolic content increased hepatic PPAR $\alpha$ gene expression in HLA-B27 transgenic rats, exerting cholesterol-lowering effects [93]. Moreover, polyphenols from different sources (coffee, olives, rice, berries, etc.) could reduce fat mass and serum/liver lipids in HFD-fed animals [94]. Especially in liver and adipose tissue, plant-derived polyphenols have been found to increase the expression of PPAR $\alpha$. Catechins and linalool are key bioactive compounds found in tea. Epigallocatechin gallate was found to not only activate PPAR $\alpha$, but also inhibit PPAR $\gamma$. Linalool also activated PPAR $\alpha$, enhanced FA uptake and utilization in the liver, and reduced plasma TAG [95]. Moreover, vitamin D down-regulated perilipin 2 and PPAR $\gamma$ and prevented lipid accumulation in muscles [96].

Another possible important modulators of PPAR activity is cellular stress, such as oxidative stress and endoplasmic reticulum (ER) stress. In many tissues, reactive oxygen species (ROS) activate the Wnt/ $\beta$-catenin pathway, leading to PPAR $\gamma$ inactivation $[97,98]$, whereas PPAR $\gamma$ agonists reduce ROS production and chronic inflammation and suppress the Wnt/ $\beta$-catenin pathway [99]. PPAR $\alpha$ signaling was found to prevent the induction of mitochondrial and ER stress and reduce the synthesis of apolipoprotein $\mathrm{B}$, thus improving the hyperlipidemia and fatty degeneration of the liver that is related to fructose intake [100]. The association between c-jun N-terminal kinase activation and PPAR $\alpha$ down-regulation has also been documented [37,101].

\section{Conclusions-Issues to Be Solved for Contributing to Human Health}

This review summarized multiple but distinct roles of PPAR in the liver, evidenced by previous experimentations using specific agonists and liver-specific PPAR-disrupted mice. There is no doubt that PPARs are intriguing therapeutic targets for metabolic syndrome, insulin resistance, dyslipidemia, and NAFLD/NASH. However, the effectiveness is still unsatisfactory and further research, improvement, and trials are needed to apply PPAR-targeted agents to human metabolic diseases. The reasons for insufficient effectiveness of PPAR activators may be derived from different roles of the three PPARs between cell types, tissues, and underlying conditions (e.g., abnormalities mainly of glucose/insulin metabolism vs. cholesterol/bile acid metabolism); different effects of PPAR 
modulation on systemic/hepatic metabolism; and different potencies to stimulate PPARs. Dual/triple agonists, combination of agonists/antagonists, and tissue-specific agonists/antagonists would be critical to obtain the benefits of PPAR activation while minimizing adverse metabolic effects. Furthermore, modulation of available agents to improve cell/tissue specificity and tissue delivery efficiency, as well as pathogenesis-based personalization/optimization of pharmacological interventions, might be useful to improve human health through PPARs.

Author Contributions: Conceptualization: N.T.; writing of the manuscript: Y.W., T.N., N.T.; critical review and supervision: F.J.G. All authors have read and agreed to the published version of the manuscript.

Acknowledgments: We thank all members of our laboratory and an emeritus Toshifumi Aoyama for their continuous support.

Conflicts of Interest: The authors declare no conflict of interest.

$\begin{array}{ll}\text { Abbreviations } & \\ \text { ACC } & \text { acetyl-coenzyme A carboxylase } \\ \text { AMPK } & \text { adenosine monophosphate-activated protein kinase } \\ \text { ATP } & \text { adenosine triphosphate } \\ \text { CCl }_{4} & \text { carbon tetrachloride } \\ \text { CD } & \text { cluster of differentiation } \\ \text { CDNA } & \text { complementary DNA } \\ \text { CoA } & \text { coenzyme A } \\ \text { ER } & \text { endoplasmic reticulum } \\ \text { FA } & \text { fatty acid } \\ \text { FABP } & \text { fatty acid-binding protein } \\ \text { FGF21 } & \text { fibroblast growth factor 21 } \\ \text { FSP27 } & \text { fat-specific protein 27 } \\ \text { HFD } & \text { high fat diet } \\ \text { HSC } & \text { hepatic stellate cell } \\ \text { IL } & \text { interleukin } \\ \text { NAFLD } & \text { non-alcoholic fatty liver disease } \\ \text { NASH } & \text { non-alcoholic steatohepatitis } \\ \text { NF- } \text { B } & \text { nuclear factor kappa B } \\ \text { PC } & \text { phosphatidylcholine } \\ \text { PP } & \text { peroxisome proliferator } \\ \text { PPAR } & \text { peroxisome proliferator-activated receptor } \\ \text { PUFA } & \text { polyunsaturated fatty acid } \\ \text { ROS } & \text { reactive oxygen species } \\ \text { SPT } & \text { serine palmitoyltransferase } \\ \text { SREBP } & \text { sterol regulatory element binding protein } \\ \text { TAG } & \text { triacylglycerol } \\ \text { TZD } & \text { thiazolidinedione } \\ \text { VLDL } & \text { very-low-density lipoprotein } \\ & \end{array}$

\section{References}

1. Reddy, J.K.; Krishnakantha, T.P. Hepatic peroxisome proliferation: Induction by two novel compounds structurally unrelated to clofibrate. Science 1975, 190, 787-789. [CrossRef]

2. Issemann, I.; Green, S. Activation of a member of the steroid hormone receptor superfamily by peroxisome proliferators. Nature 1990, 347, 645-650. [CrossRef] [PubMed]

3. Krey, G.; Keller, H.; Mahfoudi, A.; Medin, J.; Ozato, K.; Dreyer, C.; Wahli, W. Xenopus peroxisome proliferator activated receptors: Genomic organization, response element recognition, heterodimer formation with retinoid X receptor and activation by fatty acids. J. Steroid Biochem. Mol. Biol. 1993, 47, 65-73. [CrossRef] 
4. Kliewer, S.A.; Forman, B.M.; Blumberg, B.; Ong, E.S.; Borgmeyer, U.; Mangelsdorf, D.J.; Umesono, K.; Evans, R.M. Differential expression and activation of a family of murine peroxisome proliferator-activated receptors. Proc. Natl. Acad. Sci. USA 1994, 91, 7355-7359. [CrossRef] [PubMed]

5. Yu, K.; Bayona, W.; Kallen, C.B.; Harding, H.P.; Ravera, C.P.; McMahon, G.; Brown, M.; Lazar, M.A. Differential activation of peroxisome proliferator-activated receptors by eicosanoids. J. Biol. Chem. 1995, 270, 23975-23983. [CrossRef] [PubMed]

6. Narala, V.R.; Adapala, R.K.; Suresh, M.V.; Brock, T.G.; Peters-Golden, M.; Reddy, R.C. Leukotriene B4 is a physiologically relevant endogenous peroxisome proliferator-activated receptor-alpha agonist. J. Biol. Chem. 2010, 285, 22067-22074. [CrossRef]

7. O'Flaherty, J.T.; Rogers, L.C.; Paumi, C.M.; Hantgan, R.R.; Thomas, L.R.; Clay, C.E.; High, K.; Chen, Y.Q.; Willingham, M.C.; Smitherman, P.K.; et al. 5-Oxo-ETE analogs and the proliferation of cancer cells. Biochim. Biophys. Acta 2005, 1736, 228-236. [CrossRef]

8. Altmann, R.; Hausmann, M.; Spöttl, T.; Gruber, M.; Bull, A.W.; Menzel, K.; Vogl, D.; Herfarth, H.; Schölmerich, J.; Falk, W.; et al. 13-Oxo-ODE is an endogenous ligand for PPARgamma in human colonic epithelial cells. Biochem. Pharmacol. 2007, 74, 612-622. [CrossRef]

9. Takeuchi, S.; Matsuda, T.; Kobayashi, S.; Takahashi, T.; Kojima, H. In vitro screening of 200 pesticides for agonistic activity via mouse peroxisome proliferator-activated receptor (PPAR)alpha and PPARgamma and quantitative analysis of in vivo induction pathway. Toxicol. Appl. Pharmacol. 2006, 217, 235-244. [CrossRef] [PubMed]

10. Corton, J.C.; Cunningham, M.L.; Hummer, B.T.; Lau, C.; Meek, B.; Peters, J.M.; Popp, J.A.; Rhomberg, L.; Seed, J.; Klaunig, J.E. Mode of action framework analysis for receptor-mediated toxicity: The peroxisome proliferator-activated receptor alpha (PPAR $\alpha$ ) as a case study. Crit. Rev. Toxicol. 2014, 44, 1-49. [CrossRef]

11. Marion-Letellier, R.; Savoye, G.; Ghosh, S. Fatty acids, eicosanoids and PPAR gamma. Eur. J. Pharmacol. 2016, 785, 44-49. [CrossRef] [PubMed]

12. Temelkova-Kurktschiev, T.; Hanefeld, M.; Chinetti, G.; Zawadzki, C.; Haulon, S.; Kubaszek, A.; Koehler, C.; Leonhardt, W.; Staels, B.; Laakso, M. Ala12Ala genotype of the peroxisome proliferator-activated receptor gamma2 protects against atherosclerosis. J. Clin. Endocrinol. Metab. 2004, 89, 4238-4242. [CrossRef] [PubMed]

13. Matsusue, K.; Haluzik, M.; Lambert, G.; Yim, S.H.; Gavrilova, O.; Ward, J.M.; Brewer, B., Jr.; Reitman, M.L.; Gonzalez, F.J. Liver-specific disruption of PPARgamma in leptin-deficient mice improves fatty liver but aggravates diabetic phenotypes. J. Clin. Investig. 2003, 111, 737-747. [CrossRef] [PubMed]

14. Matsusue, K.; Kusakabe, T.; Noguchi, T.; Takiguchi, S.; Suzuki, T.; Yamano, S.; Gonzalez, F.J. Hepatic steatosis in leptin-deficient mice is promoted by the PPARgamma target gene Fsp27. Cell Metab. 2008, 7, 302-311. [CrossRef]

15. Aoyama, T.; Peters, J.M.; Iritani, N.; Nakajima, T.; Furihata, K.; Hashimoto, T.; Gonzalez, F.J. Altered constitutive expression of fatty acid-metabolizing enzymes in mice lacking the peroxisome proliferator-activated receptor alpha (PPARalpha). J. Biol. Chem. 1998, 273, 5678-5684. [CrossRef]

16. Nakajima, T.; Yang, Y.; Lu, Y.; Kamijo, Y.; Yamada, Y.; Nakamura, K.; Koyama, M.; Yamaguchi, S.; Sugiyama, E.; Tanaka, N.; et al. Decreased Fatty Acid $\beta$-Oxidation Is the Main Cause of Fatty Liver Induced by Polyunsaturated Fatty Acid Deficiency in Mice. Tohoku J. Exp. Med. 2017, 242, 229-239. [CrossRef]

17. Rivier, M.; Castiel, I.; Safonova, I.; Ailhaud, G.; Michel, S. Peroxisome proliferator-activated receptor-alpha enhances lipid metabolism in a skin equivalent model. J. Investig. Dermatol. 2000, 114, 681-687. [CrossRef]

18. Tian, Y.; Yang, Y.; Zhang, X.; Nakajima, T.; Tanaka, N.; Sugiyama, E.; Kamijo, Y.; Lu, Y.; Moriya, K.; Koike, K.; et al. Age-dependent PPAR $\alpha$ activation induces hepatic sulfatide accumulation in transgenic mice carrying the hepatitis C virus core gene. Glycoconj. J. 2016, 33, 927-936. [CrossRef]

19. Nakajima, T.; Kamijo, Y.; Yuzhe, H.; Kimura, T.; Tanaka, N.; Sugiyama, E.; Nakamura, K.; Kyogashima, M.; Hara, A.; Aoyama, T. Peroxisome proliferator-activated receptor $\alpha$ mediates enhancement of gene expression of cerebroside sulfotransferase in several murine organs. Glycoconj. J. 2013, 30, 553-560. [CrossRef]

20. Kimura, T.; Nakajima, T.; Kamijo, Y.; Tanaka, N.; Wang, L.; Hara, A.; Sugiyama, E.; Tanaka, E.; Gonzalez, F.J.; Aoyama, T. Hepatic Cerebroside Sulfotransferase Is Induced by PPAR $\alpha$ Activation in Mice. PPAR Res. 2012, 2012, 174932. [CrossRef]

21. Hara, A.; Kutsukake, Y.; Uemura, K.I.; Taketomi, T. Anticoagulant activity of sulfatide and its anti-thrombotic effect in rabbit. J. Biochem. 1993, 113, 781-785. [CrossRef] [PubMed] 
22. Nishimura, T.; Nakatake, Y.; Konishi, M.; Itoh, N. Identification of a novel FGF, FGF-21, preferentially expressed in the liver. Biochim. Biophys. Acta 2000, 1492, 203-206. [CrossRef]

23. Kharitonenkov, A.; Adams, A.C. Inventing new medicines: The FGF21 story. Mol. Metab. 2013, 3, $221-229$. [CrossRef] [PubMed]

24. Tanaka, N.; Takahashi, S.; Zhang, Y.; Krausz, K.W.; Smith, P.B.; Patterson, A.D.; Gonzalez, F.J. Role of fibroblast growth factor 21 in the early stage of NASH induced by methionine- and choline-deficient diet. Biochim. Biophys. Acta 2015, 1852, 1242-1252. [CrossRef]

25. Newman, J.C.; Verdin, E. $\beta$-Hydroxybutyrate: A Signaling Metabolite. Annu. Rev. Nutr. 2017, 37, 51-76. [CrossRef]

26. Kersten, S.; Seydoux, J.; Peters, J.M.; Gonzalez, F.J.; Desvergne, B.; Wahli, W. Peroxisome proliferator-activated receptor alpha mediates the adaptive response to fasting. J. Clin. Investig. 1999, 103, 1489-1498. [CrossRef]

27. Nagaya, T.; Tanaka, N.; Komatsu, M.; Ichijo, T.; Sano, K.; Horiuchi, A.; Joshita, S.; Umemura, T.; Matsumoto, A.; Yoshizawa, K.; et al. Development from simple steatosis to liver cirrhosis and hepatocellular carcinoma: A 27-year follow-up case. Clin. J. Gastroenterol. 2008, 1, 116-121. [CrossRef]

28. Hu, X.; Tanaka, N.; Guo, R.; Lu, Y.; Nakajima, T.; Gonzalez, F.J.; Aoyama, T. PPAR $\alpha$ protects against trans-fatty-acid-containing diet-induced steatohepatitis. J. Nutr. Biochem. 2017, 39, 77-85. [CrossRef]

29. Wree, A.; Broderick, L.; Canbay, A.; Hoffman, H.M.; Feldstein, A.E. From NAFLD to NASH to cirrhosis-new insights into disease mechanisms. Nat. Rev. Gastroenterol. Hepatol. 2013, 10, 627-636. [CrossRef]

30. Tanaka, N.; Aoyama, T.; Kimura, S.; Gonzalez, F.J. Targeting nuclear receptors for the treatment of fatty liver disease. Pharmacol. Ther. 2017, 179, 142-157. [CrossRef]

31. Tanaka, N.; Kimura, T.; Fujimori, N.; Nagaya, T.; Komatsu, M.; Tanaka, E. Current status, problems, and perspectives of non-alcoholic fatty liver disease research. World J. Gastroenterol. 2019, 25, 163-177. [CrossRef] [PubMed]

32. Abdelmegeed, M.A.; Yoo, S.H.; Henderson, L.E.; Gonzalez, F.J.; Woodcroft, K.J.; Song, B.J. PPARalpha expression protects male mice from high fat-induced nonalcoholic fatty liver. J. Nutr. 2011, 141, 603-610. [CrossRef]

33. Staels, B.; Rubenstrunk, A.; Noel, B.; Rigou, G.; Delataille, P.; Millatt, L.J.; Baron, M.; Lucas, A.; Tailleux, A.; Hum, D.W.; et al. Hepatoprotective effects of the dual peroxisome proliferator-activated receptor alpha/delta agonist, GFT505, in rodent models of nonalcoholic fatty liver disease/nonalcoholic steatohepatitis. Hepatology 2013, 58, 1941-1952. [CrossRef]

34. Francque, S.; Verrijken, A.; Caron, S.; Prawitt, J.; Paumelle, R.; Derudas, B.; Lefebvre, P.; Taskinen, M.R.; Van Hul, W.; Mertens, I.; et al. PPAR $\alpha$ gene expression correlates with severity and histological treatment response in patients with non-alcoholic steatohepatitis. J. Hepatol. 2015, 63, 164-173. [CrossRef]

35. Nagaya, T.; Tanaka, N.; Suzuki, T.; Sano, K.; Horiuchi, A.; Komatsu, M.; Nakajima, T.; Nishizawa, T.; Joshita, S.; Umemura, T.; et al. Down-regulation of SREBP-1c is associated with the development of burned-out NASH. J. Hepatol. 2010, 53, 724-7231. [CrossRef] [PubMed]

36. Komatsu, M.; Yazaki, M.; Tanaka, N.; Sano, K.; Hashimoto, E.; Takei, Y.; Song, Y.Z.; Tanaka, E.; Kiyosawa, K.; Saheki, T.; et al. Citrin deficiency as a cause of chronic liver disorder mimicking non-alcoholic fatty liver disease. J. Hepatol. 2008, 49, 810-820. [CrossRef] [PubMed]

37. Komatsu, M.; Kimura, T.; Yazaki, M.; Tanaka, N.; Yang, Y.; Nakajima, T.; Horiuchi, A.; Fang, Z.Z.; Joshita, S.; Matsumoto, A.; et al. Steatogenesis in adult-onset type II citrullinemia is associated with down-regulation of PPAR $\alpha$. Biochim. Biophys. Acta 2015, 1852, 473-481. [CrossRef] [PubMed]

38. Staels, B.; Koenig, W.; Habib, A.; Merval, R.; Lebret, M.; Torra, I.P.; Delerive, P.; Fadel, A.; Chinetti, G.; Fruchart, J.C.; et al. Activation of human aortic smooth-muscle cells is inhibited by PPARalpha but not by PPARgamma activators. Nature 1998, 393, 790-793. [CrossRef] [PubMed]

39. Zhang, N.; Chu, E.S.; Zhang, J.; Li, X.; Liang, Q.; Chen, J.; Chen, M.; Teoh, N.; Farrell, G.; Sung, J.J.; et al. Peroxisome proliferator activated receptor alpha inhibits hepatocarcinogenesis through mediating NF- $\mathrm{kB}$ signaling pathway. Oncotarget 2014, 5, 8330-8340. [CrossRef]

40. Chen, L.; Li, L.; Chen, J.; Li, L.; Zheng, Z.; Ren, J.; Qiu, Y. Oleoylethanolamide, an endogenous PPAR- $\alpha$ ligand, attenuates liver fibrosis targeting hepatic stellate cells. Oncotarget 2015, 6, 42530-42540. [CrossRef]

41. Brocker, C.N.; Yue, J.; Kim, D.; Qu, A.; Bonzo, J.A.; Gonzalez, F.J. Hepatocyte-specific PPAR $\alpha$ expression exclusively promotes agonist-induced cell proliferation without influence from nonparenchymal cells. Am. J. Physiol. Gastrointest. Liver Physiol. 2017, 312, G283-G299. [CrossRef] [PubMed] 
42. Montagner, A.; Polizzi, A.; Fouché, E.; Ducheix, S.; Lippi, Y.; Lasserre, F.; Barquissau, V.; Régnier, M.; Lukowicz, C.; Benhamed, F.; et al. Liver PPAR $\alpha$ is crucial for whole-body fatty acid homeostasis and is protective against NAFLD. Gut 2016, 65, 1202-1214. [CrossRef] [PubMed]

43. Smati, S.; Régnier, M.; Fougeray, T.; Polizzi, A.; Fougerat, A.; Lasserre, F.; Lukowicz, C.; Tramunt, B.; Guillaume, M.; Burnol, A.F.; et al. Regulation of hepatokine gene expression in response to fasting and feeding: Influence of PPAR- $\alpha$ and insulin-dependent signalling in hepatocytes. Diabetes Metab. 2019, in press. [CrossRef]

44. Brocker, C.N.; Patel, D.P.; Velenosi, T.J.; Kim, D.; Yan, T.; Yue, J.; Li, G.; Krausz, K.W.; Gonzalez, F.J. Extrahepatic PPAR $\alpha$ modulates fatty acid oxidation and attenuates fasting-induced hepatosteatosis in mice. J. Lipid Res. 2018, 59, 2140-2152. [CrossRef]

45. Palomer, X.; Barroso, E.; Pizarro-Delgado, J.; Pena, L.; Botteri, G.; Zarei, M.; Aguilar, D.; Montori-Grau, M.; Vázquez-Carrera, M. PPARbeta/delta: A Key Therapeutic Target in Metabolic Disorders. Int. J. Mol. Sci. 2018, 19, E913. [CrossRef]

46. Manickam, R.; Wahli, W. Roles of Peroxisome Proliferator-Activated Receptor beta/delta in skeletal muscle physiology. Biochimie 2017, 136, 42-48. [CrossRef]

47. Lee, C.H.; Olson, P.; Hevener, A.; Mehl, I.; Chong, L.W.; Olefsky, J.M.; Gonzalez, F.J.; Ham, J.; Kang, H.; Peters, J.M.; et al. PPARdelta regulates glucose metabolism and insulin sensitivity. Proc. Natl. Acad. Sci. USA 2006, 103, 3444-3449. [CrossRef]

48. Barroso, E.; Rodriguez-Calvo, R.; Serrano-Marco, L.; Astudillo, A.M.; Balsinde, J.; Palomer, X.; Vázquez-Carrera, M. The PPARbeta/delta activator GW501516 prevents the down-regulation of AMPK caused by a high-fat diet in liver and amplifies the PGC-1alpha-Lipin 1-PPARalpha pathway leading to increased fatty acid oxidation. Endocrinology 2011, 152, 1848-1859. [CrossRef] [PubMed]

49. Oliver, W.R., Jr.; Shenk, J.L.; Snaith, M.R.; Russell, C.S.; Plunket, K.D.; Bodkin, N.L.; Lewis, M.C.; Winegar, D.A.; Sznaidman, M.L.; Lambert, M.H.; et al. A selective peroxisome proliferator-activated receptor delta agonist promotes reverse cholesterol transport. Proc. Natl. Acad. Sci. USA 2001, 98, 5306-5311. [CrossRef] [PubMed]

50. Luquet, S.; Gaudel, C.; Holst, D.; Lopez-Soriano, J.; Jehl-Pietri, C.; Fredenrich, A.; Grimaldi, P.A. Roles of PPAR delta in lipid absorption and metabolism: A new target for the treatment of type 2 diabetes. Biochim. Biophys. Acta 2005, 1740, 313-317. [CrossRef]

51. Chawla, A.; Lee, C.H.; Barak, Y.; He, W.; Rosenfeld, J.; Liao, D.; Han, J.; Kang, H.; Evans, R.M. PPARdelta is a very low-density lipoprotein sensor in macrophages. Proc. Natl. Acad. Sci. USA 2003, 100, 1268-1273. [CrossRef] [PubMed]

52. Zarei, M.; Barroso, E.; Palomer, X.; Dai, J.; Rada, P.; Quesada-López, T.; Escolà-Gil, J.C.; Cedó, L.; Zali, M.R.; Molaei, M.; et al. Hepatic regulation of VLDL receptor by PPARbeta/delta and FGF21 modulates non-alcoholic fatty liver disease. Mol. Metab. 2018, 8, 117-131. [CrossRef] [PubMed]

53. Wang, Y.X.; Lee, C.H.; Tiep, S.; Yu, R.T.; Ham, J.; Kang, H.; Evans, R.M. Peroxisome-proliferator-activated receptor delta activates fat metabolism to prevent obesity. Cell 2003, 113, 159-170. [CrossRef]

54. Qin, X.; Xie, X.; Fan, Y.; Tian, J.; Guan, Y.; Wang, X.; Zhu, Y.; Wang, N. Peroxisome proliferator-activated receptor-delta induces insulin-induced gene-1 and suppresses hepatic lipogenesis in obese diabetic mice. Hepatology 2008, 48, 432-441. [CrossRef]

55. Bojic, L.A.; Telford, D.E.; Fullerton, M.D.; Ford, R.J.; Sutherland, B.G.; Edwards, J.Y.; Sawyez, C.G.; Gros, R.; Kemp, B.E.; Steinberg, G.R.; et al. PPARdelta activation attenuates hepatic steatosis in Ldlr-/- mice by enhanced fat oxidation, reduced lipogenesis, and improved insulin sensitivity. J. Lipid Res. 2014, 55, 1254-1266. [CrossRef]

56. Zingarelli, B.; Piraino, G.; Hake, P.W.; O'Connor, M.; Denenberg, A.; Fan, H.; Cook, J.A. Peroxisome proliferator-activated receptor \{delta\} regulates inflammation via NF-\{kappa\}B signaling in polymicrobial sepsis. Am. J. Pathol. 2010, 177, 1834-1847. [CrossRef]

57. Alvarez-Guardia, D.; Palomer, X.; Coll, T.; Serrano, L.; Rodriguez-Calvo, R.; Davidson, M.M.; Merlos, M.; El Kochairi, I.; Michalik, L.; Wahli, W.; et al. PPARbeta/delta activation blocks lipid-induced inflammatory pathways in mouse heart and human cardiac cells. Biochim. Biophys. Acta 2011, 1811, 59-67. [CrossRef]

58. Wahli, W.; Michalik, L. PPARs at the crossroads of lipid signaling and inflammation. Trends Endocrinol. Metab. 2012, 23, 351-363. [CrossRef]

59. Balandaram, G.; Kramer, L.R.; Kang, B.H.; Murray, I.A.; Perdew, G.H.; Gonzalez, F.J.; Peters, J.M. Ligand activation of peroxisome proliferator-activated receptor-beta/delta suppresses liver tumorigenesis in hepatitis B transgenic mice. Toxicology 2016, 363, 1-9. [CrossRef] 
60. Hellemans, K.; Michalik, L.; Dittie, A.; Knorr, A.; Rombouts, K.; De Jong, J.; Heirman, C.; Quartier, E.; Schuit, F.; Wahli, W.; et al. Peroxisome proliferator-activated receptor-beta signaling contributes to enhanced proliferation of hepatic stellate cells. Gastroenterology 2003, 124, 184-201. [CrossRef]

61. Iwaisako, K.; Haimerl, M.; Paik, Y.H.; Taura, K.; Kodama, Y.; Sirlin, C.; Yu, E.; Yu, R.T.; Downes, M.; Evans, R.M.; et al. Protection from liver fibrosis by a peroxisome proliferator-activated receptor delta agonist. Proc. Natl. Acad. Sci. USA 2012, 109, E1369-E1376. [CrossRef] [PubMed]

62. Lee, H.J.; Yeon, J.E.; Ko, E.J.; Yoon, E.L.; Suh, S.J.; Kang, K.; Kim, H.R.; Kang, S.H.; Yoo, Y.J.; Je, J.; et al. Peroxisome proliferator-activated receptor-delta agonist ameliorated inflammasome activation in nonalcoholic fatty liver disease. World J. Gastroenterol. 2015, 21, 12787-12799. [CrossRef] [PubMed]

63. Haczeyni, F.; Wang, H.; Barn, V.; Mridha, A.R.; Yeh, M.M.; Haigh, W.G.; Ioannou, G.N.; Choi, Y.J.; McWherter, C.A.; Teoh, N.C.; et al. The selective peroxisome proliferator-activated receptor-delta agonist seladelpar reverses nonalcoholic steatohepatitis pathology by abrogating lipotoxicity in diabetic obese mice. Hepatol. Commun. 2017, 1, 663-674. [CrossRef] [PubMed]

64. Silva-Veiga, F.M.; Rachid, T.L.; de Oliveira, L.; Graus-Nunes, F.; Mandarim-de-Lacerda, C.A.; Souza-Mello, V. GW0742 (PPAR-beta agonist) attenuates hepatic endoplasmic reticulum stress by improving hepatic energy metabolism in high-fat diet fed mice. Mol. Cell. Endocrinol. 2018, 474, 227-237. [CrossRef] [PubMed]

65. Gupta, R.A.; Wang, D.; Katkuri, S.; Wang, H.; Dey, S.K.; DuBois, R.N. Activation of nuclear hormone receptor peroxisome proliferator-activated receptor-delta accelerates intestinal adenoma growth. Nat. Med. 2004, 10, 245-247. [CrossRef]

66. Peters, J.M.; Gonzalez, F.J.; Muller, R. Establishing the Role of PPARbeta/delta in Carcinogenesis. Trends Endocrinol. Metab. 2015, 26, 595-607. [CrossRef]

67. Kaupang, A.; Kase, E.T.; Vo, C.X.; Amundsen, M.; Vik, A.; Hansen, T.V. Synthesis of 5-trifluoromethyl-2sulfonylpyridine PPARbeta/delta antagonists: Effects on the affinity and selectivity towards PPARbeta/delta. Bioorganic Med. Chem. 2016, 24, 247-260. [CrossRef]

68. Kaupang, A.; Paulsen, S.M.; Steindal, C.C.; Ravna, A.W.; Sylte, I.; Halvorsen, T.G.; Thoresen, G.H.; Hansen, T.V. Synthesis, biological evaluation and molecular modeling studies of the PPARbeta/delta antagonist CC618. Eur. J. Med. Chem. 2015, 94, 229-236. [CrossRef]

69. Ratziu, V.; Harrison, S.A.; Francque, S.; Bedossa, P.; Lehert, P.; Serfaty, L. GOLDEN-505 Investigator Study Group. Elafibranor, an agonist of the peroxisome proliferator-activated receptor- $\alpha$ and $-\delta$, induces resolution of nonalcoholic steatohepatitis without fibrosis worsening. Gastroenterology 2016, 150, 1147-1159. [CrossRef]

70. Liu, S.; Brown, J.D.; Stanya, K.J.; Homan, E.; Leidl, M.; Inouye, K.; Bhargava, P.; Gangl, M.R.; Dai, L.; Hatano, B.; et al. A diurnal serum lipid integrates hepatic lipogenesis and peripheral fatty acid use. Nature 2013, 502, 550-554. [CrossRef]

71. Ahmadian, M.; Suh, J.M.; Hah, N.; Liddle, C.; Atkins, A.R.; Downes, M.; Evans, R.M. PPAR $\gamma$ signaling and metabolism: The good, the bad and the future. Nat. Med. 2013, 19, 557-566. [CrossRef] [PubMed]

72. Nadra, K.; Quignodon, L.; Sardella, C.; Joye, E.; Mucciolo, A.; Chrast, R.; Desvergne, B. PPARgamma in placental angiogenesis. Endocrinology 2010, 151, 4969-4981. [CrossRef] [PubMed]

73. Yu, S.; Matsusue, K.; Kashireddy, P.; Cao, W.Q.; Yeldandi, V.; Yeldandi, A.V.; Reddy, J.K. Adipocyte-specific gene expression and adipogenic steatosis in the mouse liver due to peroxisome proliferator-activated receptor gamma1 (PPARgamma1) overexpression. J. Biol. Chem. 2003, 278, 498-505. [CrossRef] [PubMed]

74. Lee, Y.J.; Ko, E.H.; Kim, J.E.; Kim, E.; Lee, H.; Choi, H.; Yu, J.H.; Kim, H.J.; Seong, J.K.; Kim, K.S.; et al. Nuclear receptor PPARgamma-regulated monoacylglycerol O-acyltransferase 1 (MGAT1) expression is responsible for the lipid accumulation in diet-induced hepatic steatosis. Proc. Natl. Acad. Sci. USA 2012, 109, 13656-13661. [CrossRef] [PubMed]

75. Yamazaki, T.; Shiraishi, S.; Kishimoto, K.; Miura, S.; Ezaki, O. An increase in liver PPARgamma2 is an initial event to induce fatty liver in response to a diet high in butter: PPARgamma2 knockdown improves fatty liver induced by high-saturated fat. J. Nutr. Biochem. 2011, 22, 543-553. [CrossRef]

76. Lee, Y.K.; Park, J.E.; Lee, M.; Hardwick, J.P. Hepatic lipid homeostasis by peroxisome proliferator-activated receptor gamma 2. Liver Res. 2018, 2, 209-215. [CrossRef]

77. Motomura, W.; Inoue, M.; Ohtake, T.; Takahashi, N.; Nagamine, M.; Tanno, S.; Kohgo, Y.; Okumura, T. Up-regulation of ADRP in fatty liver in human and liver steatosis in mice fed with high fat diet. Biochem. Biophys. Res. Commun. 2006, 340, 1111-1118. [CrossRef] 
78. Wang, F.; Mullican, S.E.; DiSpirito, J.R.; Peed, L.C.; Lazar, M.A. Lipoatrophy and severe metabolic disturbance in mice with fat-specific deletion of PPARgamma. Proc. Natl. Acad. Sci. USA 2013, 110, 18656-18661. [CrossRef]

79. Tanaka, N.; Takahashi, S.; Matsubara, T.; Jiang, C.; Sakamoto, W.; Chanturiya, T.; Gonzalez, F.J. Adipocyte-specific disruption of fat-specific protein 27 causes hepatosteatosis and insulin resistance in high-fat diet-fed mice. J. Biol. Chem. 2015, 290, 3092-3105. [CrossRef]

80. Tanaka, N.; Horiuchi, A.; Yokoyama, T.; Kaneko, G.; Horigome, N.; Yamaura, T.; Nagaya, T.; Komatsu, M.; Sano, K.; Miyagawa, S.; et al. Clinical characteristics of de novo nonalcoholic fatty liver disease following pancreaticoduodenectomy. J. Gastroenterol. 2011, 46, 758-768. [CrossRef]

81. Nagaya, T.; Tanaka, N.; Kimura, T.; Kitabatake, H.; Fujimori, N.; Komatsu, M.; Horiuchi, A.; Yamaura, T.; Umemura, T.; Sano, K.; et al. Mechanism of the development of nonalcoholic steatohepatitis after pancreaticoduodenectomy. BBA Clin. 2015, 3, 168-174. [CrossRef] [PubMed]

82. Scherer, P.E.; Williams, S.; Fogliano, M.; Baldini, G.; Lodish, H.F. A novel serum protein similar to C1q, produced exclusively in adipocytes. J. Biol. Chem. 1995, 270, 26746-26749. [CrossRef] [PubMed]

83. Ye, R.; Scherer, P.E. Adiponectin, driver or passenger on the road to insulin sensitivity? Mol. Metab. 2013, 2, 133-141. [CrossRef] [PubMed]

84. Chinetti, G.; Fruchart, J.C.; Staels, B. Peroxisome proliferator-activated receptors: New targets for the pharmacological modulation of macrophage gene expression and function. Curr. Opin. Lipidol. 2003, 14, 459-468. [CrossRef]

85. Konstantinopoulos, P.A.; Vandoros, G.P.; Sotiropoulou-Bonikou, G.; Kominea, A.; Papavassiliou, A.G. NF-kappaB/PPAR gamma and/or AP-1/PPAR gamma 'on/off' switches and induction of CBP in colon adenocarcinomas: Correlation with COX-2 expression. Int. J. Colorectal Dis. 2007, 22, 57-68. [CrossRef]

86. Bouhlel, M.A.; Derudas, B.; Rigamonti, E.; Dievart, R.; Brozek, J.; Haulon, S.; Zawadzki, C.; Jude, B.; Torpier, G.; Marx, N.; et al. PPARgamma activation primes human monocytes into alternative M2 macrophages with anti-inflammatory properties. Cell Metab. 2007, 6, 137-143. [CrossRef]

87. Miyahara, T.; Schrum, L.; Rippe, R.; Xiong, S.; Yee, H.F., Jr.; Motomura, K.; Anania, F.A.; Willson, T.M.; Tsukamoto, H. Peroxisome proliferator-activated receptors and hepatic stellate cell activation. J. Biol. Chem. 2000, 275, 35715-35722. [CrossRef]

88. Bae, M.A.; Rhee, S.D.; Jung, W.H.; Ahn, J.H.; Song, B.J.; Cheon, H.G. Selective inhibition of activated stellate cells and protection from carbon tetrachloride-induced liver injury in rats by a new PPARgamma agonist KR62776. Arch. Pharm. Res. 2010, 33, 433-442. [CrossRef]

89. Gavrilova, O.; Haluzik, M.; Matsusue, K.; Cutson, J.J.; Johnson, L.; Dietz, K.R.; Nicol, C.J.; Vinson, C.; Gonzalez, F.J.; Reitman, M.L. Liver peroxisome proliferator-activated receptor gamma contributes to hepatic steatosis, triglyceride clearance, and regulation of body fat mass. J. Biol. Chem. 2003, 278, 34268-34276. [CrossRef]

90. Wei, Z.; Zhao, D.; Zhang, Y.; Chen, Y.; Zhang, S.; Li, Q.; Zeng, P.; Li, X.; Zhang, W.; Duan, Y.; et al. Rosiglitazone ameliorates bile duct ligation-induced liver fibrosis by down-regulating NF-kappaB-TNF-alpha signaling pathway in a PPARgamma-dependent manner. Biochem. Biophys. Res. Commun. 2019, 519, 854-860. [CrossRef]

91. Moran-Salvador, E.; Lopez-Parra, M.; Garcia-Alonso, V.; Titos, E.; Martinez-Clemente, M.; Gonzalez-Periz, A.; López-Vicario, C.; Barak, Y.; Arroyo, V.; Clària, J. Role for PPARgamma in obesity-induced hepatic steatosis as determined by hepatocyte- and macrophage-specific conditional knockouts. FASEB J. Off. Publ. Fed. Am. Soc. Exp. Biol. 2011, 25, 2538-2550. [CrossRef]

92. Moran-Salvador, E.; Titos, E.; Rius, B.; Gonzalez-Periz, A.; Garcia-Alonso, V.; Lopez-Vicario, C.; Miquel, R.; Barak, Y.; Arroyo, V.; Clària, J. Cell-specific PPARgamma deficiency establishes anti-inflammatory and anti-fibrogenic properties for this nuclear receptor in non-parenchymal liver cells. J. Hepatol. 2013, 59, 1045-1053. [CrossRef] [PubMed]

93. Bigagli, E.; Toti, S.; Lodovici, M.; Giovannelli, L.; Cinci, L.; D’Ambrosio, M.; Luceri, C. Dietary Extra-Virgin Olive Oil Polyphenols Do Not Attenuate Colon Inflammation in Transgenic HLAB-27 Rats but Exert Hypocholesterolemic Effects through the Modulation of HMGCR and PPAR-alpha Gene Expression in the Liver. Lifestyle Genom. 2018, 11, 99-108. [CrossRef] [PubMed]

94. Dominguez-Avila, J.A.; Gonzalez-Aguilar, G.A.; Alvarez-Parrilla, E.; de la Rosa, L.A. Modulation of PPAR Expression and Activity in Response to Polyphenolic Compounds in High Fat Diets. Int. J. Mol. Sci. 2016, 17, 1002. [CrossRef] [PubMed] 
95. Lee, S.J.; Jia, Y. The effect of bioactive compounds in tea on lipid metabolism and obesity through regulation of peroxisome proliferator-activated receptors. Curr. Opin. Lipidol. 2015, 26, 3-9. [CrossRef]

96. Li, J.; Mihalcioiu, M.; Li, L.; Zakikhani, M.; Camirand, A.; Kremer, R. Vitamin D prevents lipid accumulation in murine muscle through regulation of PPARgamma and perilipin-2 expression. J. Steroid Biochem. Mol. Biol. 2018, 177, 116-124. [CrossRef]

97. Ajmone-Cat, M.A.; D’Urso, M.C.; di Blasio, G.; Brignone, M.S.; De Simone, R.; Minghetti, L. Glycogen synthase kinase 3 is part of the molecular machinery regulating the adaptive response to LPS stimulation in microglial cells. Brain Behav. Immun. 2016, 55, 225-235. [CrossRef]

98. Jansson, E.A.; Are, A.; Greicius, G.; Kuo, I.C.; Kelly, D.; Arulampalam, V.; Pettersson, S. The Wnt/beta-catenin signaling pathway targets PPARgamma activity in colon cancer cells. Proc. Natl. Acad. Sci. USA 2005, 102, 1460-1465. [CrossRef]

99. Vallee, A.; Lecarpentier, Y. Crosstalk Between Peroxisome Proliferator-Activated Receptor Gamma and the Canonical WNT/beta-Catenin Pathway in Chronic Inflammation and Oxidative Stress During Carcinogenesis. Front. Immunol. 2018, 9, 745. [CrossRef]

100. Su, Q.; Baker, C.; Christian, P.; Naples, M.; Tong, X.; Zhang, K.; Santha, M.; Adeli, K. Hepatic mitochondrial and ER stress induced by defective PPARalpha signaling in the pathogenesis of hepatic steatosis. American journal of physiology. Endocrinol. Metab. 2014, 306, E1264-E1273.

101. Lu, Y.; Liu, X.; Jiao, Y.; Xiong, X.; Wang, E.; Wang, X.; Zhang, Z.; Zhang, H.; Pan, L.; Guan, Y.; et al. Periostin promotes liver steatosis and hypertriglyceridemia through downregulation of PPARalpha. J. Clin. Investig. 2014, 124, 3501-3513. [CrossRef] [PubMed]

(C) 2020 by the authors. Licensee MDPI, Basel, Switzerland. This article is an open access article distributed under the terms and conditions of the Creative Commons Attribution (CC BY) license (http://creativecommons.org/licenses/by/4.0/). 